\title{
Evaluation of Cluster Front Line Demonstration in Greengram Crop
}

\author{
Kabita Mishra*, S. Panigrahi and D. Sarangi \\ Krishi Vigyan Kendra, Ganjam-II, Odisha, India \\ *Corresponding author
}

\section{A B S T R A C T}

\begin{tabular}{|l|}
\hline Ke y w o r d s \\
Greengram, Cluster front \\
line demonstration, Seed \\
yield, B: C ratio, \\
Technology gap
\end{tabular}

Front line demonstration is an appropriate means for demonstration as well as transfer of improved agricultural innovations to the farming community. It provides an opportunity to researchers and extension personnel for understanding the farmer's resources and requirement to modify the technologies for easy adaptability at farmer's fields. Krishi Vigyan Kendra, Ganjam-II has conducted Cluster Front Line Demonstration on greengram at farmers' fields in the adopted village Rajanapalli during Rabi 2017. The KVK scientists have conducted 50 Cluster frontline demonstration in 20 hectares area by the active participation of farmers with the objective to demonstrate the improved technologies in greengram crop. The improved technologies consisting use of improved variety, seed treatment with Rhizobium culture, integrated nutrient and weed management, pest and disease management. The results revealed that the highest seed yield was obtained in demonstrated plot with an average of $701 \mathrm{~kg} / \mathrm{ha}$ as compared to $550 \mathrm{~kg} / \mathrm{ha}$. Higher net return (15850Rs/ha) was obtained in the demonstration plots compared to farmers practice plots (9050Rs/ha).

\section{Introduction}

Pulse is the most important food crop in India. It is the second most important group after cereals which play a key role in Indian Agriculture. Their ability to use atmospheric nitrogen through biological nitrogen fixation is economically more sound and environment friendly. Pulses are a good source of protein for a majority of the Indian population. India is the major pulse producing country in the world which shares $30-35 \%$ and $27-28 \%$ of the total area and production of pulse respectively. Even though pulse production increased significantly during last decade growth but maintaining that trend is a challenge for researcher, extension agencies and policy makers to fulfill the domestic demand. The productivity of pulse in India $(694 \mathrm{~kg} / \mathrm{ha})$ is lower than most of major pulse producing countries. In year $2016-17$ the total pulse area 238.56 lakh ha with production in India was18.25 million tonnes with productivity $765 \mathrm{~kg} \mathrm{ha}^{-1}$. Greengram is one of the most important pulse crops. It contains 25 percent of high digestible proteins and consumed both as whole grain as well as split dal. It is a soil building crop which fixes atmospheric nitrogen through symbiotic action and can also be used as green manure crop adding $34 \mathrm{~kg} \mathrm{~N} \mathrm{ha}{ }^{-1}$. Green gram or mung bean (Vigna radiata L.) is the major pulse 
crop of the state Odisha covering total area of 8.36 lakh ha with average productivity $434 \mathrm{~kg}$ per ha, which is about 40 percent of the total pulse area of the state. The district of Ganjam lies in two agro climatic zones i.e. East \& South Eastern coastal plain zone and North Eastern Ghat Zone of Odisha extending from $18^{0} 13^{\prime} \mathrm{N}$ to $19^{0} 10^{\prime}$ North latitude to $82^{0} 5^{\prime}$ to $83^{\circ} 23$ ' East longitude. The Average Normal Rainfall of this district is $1276.2 \mathrm{~mm}$ and more than $75 \%$ of the precipitation is received over five months i.e. June- October. Agriculture is the primary occupation of inhabitants of this district. The maximum and minimum temperature of this district is $39^{\circ} \mathrm{C}$ and $18.9^{\circ} \mathrm{C}$ respectively. Farmers of the district adopt the rice-pulse (greengram) cropping system to utilize the residual soil moisture after the harvest of kharif rice which increase the soil fertility status, as well as yield and income of the farmer. Green gram is cultivated as major pulse crop in the district comprising total area of 159,420 ha with productivity of $976 \mathrm{~kg} \mathrm{ha}^{-1}$, which is very low. The farmers are using local cultivators i.e. Chaiti Muga which gives poor yield due to non-adoption of any soil test based fertilizer application. Disease like YMV is the major bottleneck to achieve higher productivity in greengram.

It is therefore necessary to assess the technological gap in production and also to know the problems and constraints in adopting new production technologies.

KVKs are grassroot level organization meant for application of technology through assessment, refinement and demonstration of proven technologies under different microfarming situation in a district (Das, 2010). The main objective of cluster front line demonstration was to increase the greengram production through improved crop management practices. The newly and innovative technology having higher production potential under the specific cropping system can be popularized the demonstration programme.

The present study was undertaken to evaluate the performance of cluster front line demonstration in greengram crop.

\section{Materials and Methods}

The present study was carried out in adopted village Rajanapalli of Krishi Vigyan Kendra (KVK), Ganjam-II during Rabi 2017-18. The study was under taken in Rajanapalli village Chatrapur block of Ganjam district of Odisha and the block was selected purposefully as green gram is the major crop in Rabi season. The geographic location of the area was with $82^{0} 5^{\prime}$ to $83^{0} 23^{\prime}$ East Longitude $18^{0} 13^{\prime} \mathrm{N}$ to $19^{0} 10^{\prime}$ North Latitude and soil and nutrient status of the experimental site is given below. The climate of the region is hot and humid climate with average rainfall $1276 \mathrm{~mm}$. The soil status of CFLD's is depicted in Table 1. The improved technology such as improved variety, ICM practices like seed treatment, INM, weed management and IPM was maintained during the crop period.

The field was ploughed two times and planking was done after each ploughing then seeds were inoculated with Rhizobium culture@20.0gm per kg of seed and sown in line by using seed cum fertilizer drill with spacing $20 \times 10 \mathrm{~cm}$ and seed rate was $20 \mathrm{~kg} / \mathrm{ha}$. Soil test based fertilizer application was recommended with fertilizer dose NPK $20: 40: 20 \mathrm{~kg}$ ha-1 and applied as basal. Spraying of thiamethoxam@5gm/15 lit of water for control of sucking pests. Weed management through application of Imazethapyr@300 ml /ac was done. The seeds and other critical inputs were supplied to the farmers by KVK.

The data were collected through personal contact with farmers at farmer's field and after 
that tabulated and analyzed to find out the findings and conclusion. The statistical tool like percentage used in this study for analyzed data. The extension gap, technology gap and the technology index were work out with the help of formulas given by Samui et al., (2000) as mentioned below:

Extension gap $=$ Demonstration yield-farmers' yield (control)

Technology gap $=$ Potential yielddemonstration yield

Technology index $=$ Potential Yield Demonstration Yield/ Potential Yield x 100

\section{Results and Discussion}

Differentiation in farmer's practices and demonstration package in greengram crop

The major differences were observed between demonstration package and farmer's practices are regarding recommended varieties, seed treatment, method of sowing, fertilizer dose, method of fertilizer application, weed management and plant protection measures.

Table 2 shows that under the demonstrated plot only recommended varieties, seed treating culture, herbicide and plant protection chemicals were given to farmer by the KVK and other practices were timely performed by the farmer itself under supervision of KVK scientist. Under farmer's practice, they generally sow seed of greengram at higher seed rate without treatment. The local variety i.e. chaiti muga was found susceptible to yellow vein mosaic disease. Therefore the farmers selected under CFLD programme were provided with the seed of YVM resistance green gram var IPM-02-14. The IPM-02-14 (Shreya) variety, being resistant to mungbean yellow mosaic virus, powdery mildew and leaf crinkling incidence led to lower cost of cultivation resulting to higher net return as compared to local variety.

\section{Yield performance}

The seed yield of demonstration plots was higher as compared to farmers practice due to high yielding variety and other integrated crop management practices. A comparison of yield performance between demonstrated practices and local checks is shown in Table 3. The variety IPM-02-14 gives higher yield as compared to local variety Chaiti Mung. It was observed that the seed yield was $7.1 \mathrm{q} / \mathrm{ha}$ which was higher as compared to farmer practice $5.5 \mathrm{q} / \mathrm{ha}$. The increase in the yield over local check was $29.1 \%$. Similar yield enhancement in different crops in front line demonstration has been documented by Poonia and Pithia (2011), Patel et al., (2013) and Raj et al., (2013). Yield of the front line demonstration trials and potential yield of the crop was compared to estimate the yield gaps which were further categorized into technology and extension gaps (Hiremath and Nagaraju, 2009).

\section{Extension gap}

The extension gap is the difference or gap between demonstration yield and farmers practices (control). The average extension gap between demonstration practices and farmers practices was recorded $1.6 \mathrm{q} / \mathrm{ha}$ (Table 4). This extension gap should be assigned to adoption of improved transfer technology in demonstrations practices resulted in higher seed yield than traditional farmer practices. This emphasized the need to educate the farmers through various means for more adoption of improved high yielding varieties and newly improved agricultural technologies to bridge the wide extension gap. More use of new high yielding varieties by the farmers will subsequently change this alarming trend of galloping extension gap. 
Table.1 Soil nutrient status of the demonstration plot

\begin{tabular}{|l|l|}
\hline Soil test report & Demonstration plot \\
\hline Ph & 5.4 \\
\hline EC $(\mathrm{dS} \mathrm{m}-1)$ & 0.20 \\
\hline Available $\mathrm{N}\left(\mathrm{Kg} \mathrm{ha}^{-1}\right)$ & 166.31 \\
\hline Available P2O5 $\left(\mathrm{Kg} \mathrm{ha}^{-1}\right)$ & 12.45 \\
\hline Available $\mathrm{K} 20\left(\mathrm{Kg} \mathrm{ha}^{-1}\right)$ & 144.10 \\
\hline Organic carbon $(\%)$ & 0.55 \\
\hline
\end{tabular}

Table.2 Differences between farmer's practices and technological intervention for Greengram crop

\begin{tabular}{|c|c|c|c|}
\hline $\begin{array}{l}\text { SI. } \\
\text { No. }\end{array}$ & Practices & Demonstrated practice & Farmers' practice \\
\hline 1 & Field preparation & 2 ploughings & single plough \\
\hline 2 & Method of sowing & Line sowing behind the plough & Broad casting \\
\hline 3 & Variety & IPM02-14 & Chaiti muga \\
\hline 4 & Seed treatment & Seed inoculation with Rhizobium culture & No seed treatment \\
\hline 5 & Seed rate \& spacing & $20 \mathrm{~kg} / \mathrm{ha}$ and $20 \times 10 \mathrm{~cm}$ & $30 \mathrm{~kg} / \mathrm{ha}$ \\
\hline 6 & Manures \&Fertilizers & Soil test based fertilizer application & $\begin{array}{l}\text { injudicious use of } \\
\text { chemical fertilizers }\end{array}$ \\
\hline 7 & Weed management & $\begin{array}{l}* \text { weed management through application } \\
\text { of Imazethapyr @ } 300 \mathrm{ml} / \mathrm{ac}\end{array}$ & No herbicide application \\
\hline 8 & IPM Measures & $\begin{array}{l}\text { Plant protection chemical } \\
\text { thiamethoxam @5gm/15 lit of water for control } \\
\text { of sucking pests. }\end{array}$ & $\begin{array}{l}\text { Indiscriminate usage of } \\
\text { pesticides }\end{array}$ \\
\hline
\end{tabular}

Table.3 Productivity, extension gap, technology gap and technology index of Greengram as grown under demonstration

\begin{tabular}{|l|l|l|l|l|l|}
\hline Variables & Yield (q/ha) & $\begin{array}{l}\% \\
\text { over increase } \\
\text { check }\end{array}$ & $\begin{array}{l}\text { Extension } \\
\text { gap (q/ha) }\end{array}$ & $\begin{array}{l}\text { Technology } \\
\text { gap (q/ha) }\end{array}$ & $\begin{array}{l}\text { Technology } \\
\text { index (\%) }\end{array}$ \\
\hline $\begin{array}{l}\text { farmer } \\
\text { practice }\end{array}$ & 5.5 & & & & \\
\hline Demo & 7.1 & 29.1 & 1.6 & 1.9 & 21 \\
\hline
\end{tabular}

Table.4 Economics of front line demonstration

\begin{tabular}{|l|l|l|l|l|}
\hline Variables & $\begin{array}{l}\text { Gross cost of } \\
\text { cultivation (Rs/ha) }\end{array}$ & $\begin{array}{l}\text { Gross return } \\
\text { (Rs/ha) }\end{array}$ & $\begin{array}{l}\text { Net return } \\
\text { (Rs/ha) }\end{array}$ & B: C ratio \\
\hline farmer practice & 21200 & 30250 & 9050 & 1.42 \\
\hline Demo & 23200 & 39050 & 15850 & 1.68 \\
\hline
\end{tabular}



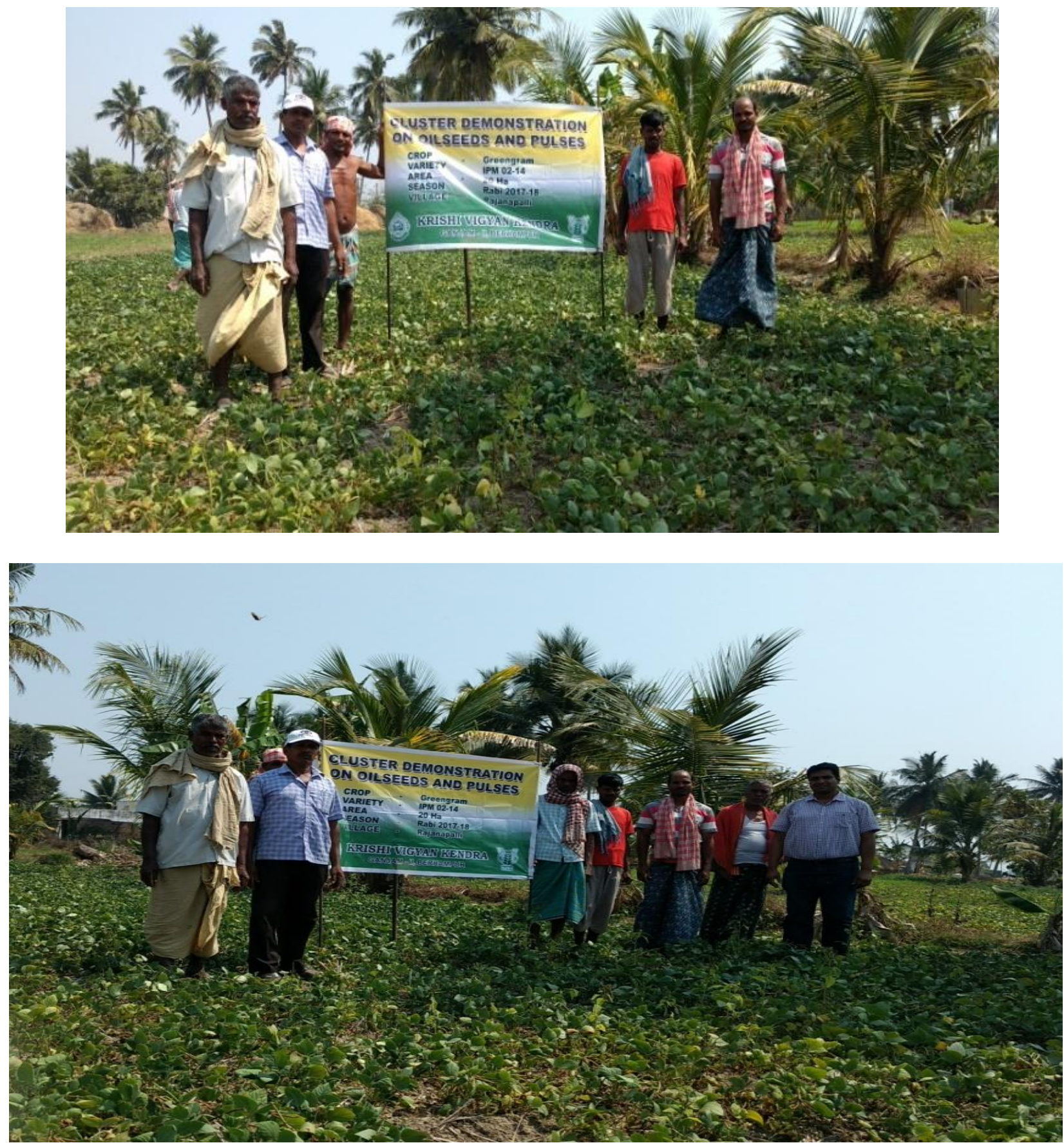

The new technologies will eventually lead to the farmers to discontinuance of old varieties with the new technology.

\section{Technology gap}

The technology gap is the difference or gap between the demonstration yield and potential yield. It was found $1.9 \mathrm{q} / \mathrm{ha}$. The technology gap observed may be attributed to dissimilarity in the soil fertility status and weather conditions. Hence location specific recommendation appears to be necessary to bridge the gap between the yields. These findings are similar to the findings of Patel $e t$ al., (2013). 


\section{Technology index}

The Technology index shows the feasibility of the technology at the farmer's field. The lower the value of technology index more is the feasibility. The Result of the present study depicted in Table 3 revealed that the technology index value is 21 percent. This indicates that a gap existed between technology evolved and technology adoption at farmer's field. The similar results were also observed by Gangadevi et al., (2017), Kumar et al., (2014), Thakral and Bhatnagar (2002), Bairwa et al., (2013), Hiremath and Nagaraju, (2010) and Dhaka et al., (2010).

\section{Economics of front line demonstration}

The economics of green gram production under front line demonstrations have been presented in Table 4 . The results of economic analysis of green gram production revealed that cost of cultivation increased in demonstration practice (23200 Rs/ha) as compared to Farmers practice plot check (21200 Rs/ha). It was observed that front line demonstrations recorded higher gross returns (Rs 39050/ha) and net returns (Rs 15850/ha). The benefit cost ratio of demonstration plot (1.68) was also more than the farmers practice (1.42)

The findings of the study showed that the integration of improved technology and tha training along with active participation of farmer has a positive effect on increase the seed yield and economic return of green gram crop. Based on study the economic viability of the demonstration motivated the farmers towards adoption of interventions demonstrated.

This will subsequently increase the income as well as the livelihood of the farming community besides enhancing soil fertility. The per cent increment in yield of greengram to the extent of $29.1 \%$ in demonstration over the farmers practice created greater awareness and motivated the other farmers to adopt the improved package of practices of greengram. These demonstrations built the relationship and confidence between farmers and KVK scientists. It is concluded that the CFLD programme is an effective tool for increasing the production and productivity of greengram and changing the knowledge, attitude and skill of the farmers. This has not only resulted in socio-economic security but also helped in attaining food and nutrition security to the community along with fodder requirement of farm animals.

\section{Acknowledgement}

Krishi Vigyan Kendra Ganjam-II is thankful to the Director, ICAR-ATARI, Zone-V, KOLKATA for providing funds for conducting the CFLDs and farmers who always show faith in the Krishi Vigyan Kendra Ganjam-II.

\section{References}

Bairwa, R. K., S. R. Verma, K. Chayal and N. L. Meena 2013. Popularization of Improved Black gram Production Technology through Front line demonstration in humid southern plain of Rajasthan, Indian Journal of Extension Education and R.D. 21: 97101.

Das Mamoni, Puzari N N and Ray B K 2010. Impact of training of skill and knowledge development of rural women, Agricultural Extension Review, 1(1): 29-30

Dhaka, B.L, Meena, B.S. and Suwalka, R. L. 2010. Popularization of improved maize technology through Frontline Demonstration in South-eastern Rajasthan, Journal of Agricultural Sciences, (1):39-42 
Ganga Devi, CH. Anil Kumar and Yugandhar Kumar, M. 2018. Performance Evaluation of Cluster Front Line Demonstration in Blackgram. Int.J.Curr.Microbiol.App.Sci. $\quad 7(08)$ : 4349-4354.

Ganga Devi, M., Anil Kumar, $\mathrm{CH}$ and Srinivas Kumar, D. Impact analysis of trainings and frontline demonstrations in Black Gram (Vigna mungo) cultivation. J Krishi Vigyan 2017, 6(1): 97-100

Hiremath S M and Nagaraju M V 2009. Evaluation of front line demonstration trials on onion in Haveri district of Karnataka, Karnataka J Agric Sci 22 (5):1092-1093

Hiremath SM and Nagaraju MV 2010. Evaluation of on front line demonstrations on the yield of chilli, Karnataka J. Agric. Sci., 23 (2): 341342.

Kumar S, Singh R and Singh A (2014). Assessment of gaps in pulse production in Hamirpur district of Himachal Pradesh. Indian Res J Ext Edu 14 (2): 20-24
Patel, H.R., Patel, F.H., Maheriya, V.D and Dodia, I.N 2013. Response of Kharif green gram (Vigna radiata L) to Sulphur and Phosphorus with and without biofertilizer application. Bioscan, 8(1):149-152.

Poonia TC and Pithia MS 2011. Impact of front line demonstrations of chickpea in Gujarat, Legume Reeserach, 34(4): 304307

Raj AD, Yadav V, Rathod JH. Impact of front line demonstrations (FLD) on the yield of pulses. Internat. J Scient. \& Res. Public. 2013; 3(9):1-4.

Samui, S.K., Maitra, S., Roy, D.K., Mondal, A.K. and Saha, D. 2000. Evaluation of front line demonstration on groundnut (Arachis hypogea L.) in Sundarbans, Journal of Indian Society of Coastal Agriculture Resources, 18(2): 180-183.

Thakral, S. K. and Bhatnagar, P. 2002. Evaluation of frontline demonstrations on Chickpea in north-western region of Haryana, Agric. Sci. Digest, 22 (3):217218

\section{How to cite this article:}

Kabita Mishra, S. Panigrahi and Sarangi, D. 2018. Evaluation of Cluster Front Line Demonstration in Greengram Crop. Int.J.Curr.Microbiol.App.Sci. 7(10): 3344-3350.

doi: https://doi.org/10.20546/ijcmas.2018.710.387 